\title{
Methimazole inhibits CXC chemokine ligand 10 secretion in human thyrocytes
}

\author{
C Crescioli ${ }^{1}$, L Cosmi ${ }^{2}$, E Borgogni ${ }^{1}$, V Santarlasci ${ }^{2}$, S Gelmini ${ }^{1}$, M Sottili ${ }^{1}$, E Sarchielli ${ }^{4}$, B Mazzinghi ${ }^{1}$, \\ M Francalanci ${ }^{1}$, A Pezzatini ${ }^{1}$, G Perigli ${ }^{3}$, G B Vannelli ${ }^{4}$, F Annunziato ${ }^{2}$ and M Serio $^{1}$ \\ Departments of ${ }^{1}$ Clinical Pathophysiology, ${ }^{2}$ Internal Medicine, Center for Research Transfer and High Education 'DENOthe', ${ }^{3}$ General Surgery Medical School \\ and ${ }^{4}$ Anatomy, Histology and Forensic Medicine, University of Florence, Florence, Italy \\ (Correspondence should be addressed to C Crescioli who is now at Unit of Endocrinology, Department of Clinical Pathophysiology, University of Florence, Viale \\ Pieraccini 6, 50139 Florence, Italy; Email: c.crescioli@dfc.unifi.it)
}

\begin{abstract}
CXC chemokine ligand 10 (CXCL10) plays a pivotal role in the self-perpetuation of the inflammatory processes in patients with autoimmune thyroid disease. Treatment with methimazole (MMI) reduces serum CXCL10 in patients with Graves' disease. In isolated human thyrocytes, tumor necrosis factor (TNF) $\alpha$ demonstrates a potent synergistic effect on interferon (IFN) $\gamma$-induced CXCL10 secretion. We investigated the mechanism underlying the synergism between IFN $\gamma$ and TNF $\alpha$ and the effect of MMI on CXCL10 secretion in human thyrocytes. A peroxisome proliferatoractivated receptor $\gamma$ agonist, rosiglitazone (RGZ), a known inhibitor of T helper 1 (Th1)-mediated responses, was also studied for comparison. Experiments were carried out in human thyrocytes isolated from internodular parenchyma of thyroid tissues derived from patients who had undergone surgery for multinodular goiter. ELISA was used to measure CXCL10 levels in culture supernatant. Flow cytometry was
\end{abstract}

used to assess IFN $\gamma$ membrane receptor expression. Specific mRNA analysis was performed by Taqman real-time PCR. Immunofluorescence was performed to detect nuclear translocation of nuclear factor- $\kappa \mathrm{B}(\mathrm{NF}-\kappa \mathrm{B})$. In human thyrocytes, the synergistic effect of TNF $\alpha$ with IFN $\gamma$ on CXCL10 secretion is due to the upregulation of IFN $\gamma$ receptor expression. MMI decreased cytokine-induced CXCL10 secretion by reducing TNF $\alpha$-induced upregulation of the IFN $\gamma$ receptor. RGZ decreased the cytokine-induced CXCL10 secretion by impairing NF- $\kappa \mathrm{B}$ translocation, without affecting IFN $\gamma$ receptor. MMI and RGZ targeted thyrocytes with the same pharmacological potency, likely acting throughout different mechanisms. Targeting $\mathrm{T}$ helper 1-mediated autoimmune thyroid disease with drugs that impair different intracellular pathways could be a novel pharmacological tool.

Journal of Endocrinology (2007) 195, 145-155

\section{Introduction}

In the pathogenesis of human autoimmune thyroid disorders (AITDs), Hashimoto's thyroiditis and Graves' disease (GD), intrathyroidal lymphocytes seem to play a central role since thyroid antigen recognition is an essential step to $\mathrm{T}$ - and/or B-cell stimulation (Weetman \& McGregor 1994). The T-cell pattern involved in GD might change throughout the disease course, with T helper 1 (Th1) as the predominant subtype of $\mathrm{CD} 4{ }^{+} \mathrm{T}$ cells in patients with recent disease onset and $\mathrm{Th} 2$ as the predominant subtype in patients with longer disease duration (Aniszewski et al. 2000).

In AITDs, a wide range of Th1-associated cytokines, such as interleukin (IL)-1, IL-2, IL-6, interferon (IFN) $\gamma$, and tumor necrosis factor (TNF) $\alpha$, are produced. The cytokine production in AITDs has been ascribed to infiltrating $\mathrm{T}$ cells, macrophages (Weetman 2003), thyrocytes (Watson et al. 1995, Weetman 2004), and endothelial cells (Romagnani et al. 2002). The active phase of the disease is characterized by the presence of proinflammatory and Th1-derived cytokines in the thyroid gland, whereas Th2-derived cytokines do not seem to be involved (Wakelkamp et al. 2003).

Chemokines, a group of low-molecular-weight peptides belonging to the cytokine family, are known to induce the chemotaxis of different leucocyte subtypes (Zlotnik \& Yoshie 2000). The CXC chemokines inducible by IFN $\gamma-$ CXCL9, CXCL10, and CXCL11 - are associated with Th1-mediated immune responses (Antonelli et al. 2006a). CXCL10, in particular, has been identified as a prototypic chemokine involved in the pathogenesis of glandular autoimmunity (Romagnani et al. 2002, Rotondi et al. 2003, Antonelli et al. 2004, 2005). Indeed, CXCL10 and its CXCR 3 receptor play a pivotal role in the initial phases of AITDs (Romagnani et al. 2002, Kemp et al. 2003). In patients with GD, CXCL10 was detected in thyrocytes and endothelial and inflammatory cells, which also expressed peculiarly a large amount of CXCR3 (Garcia-Lopez et al. 2001, Romagnani et al. 2001, Aust et al. 2002, Kemp et al. 2003, Antonelli et al. 2004, 2005). 
Furthermore, CXCL10 serum levels were significantly increased in GD patients with recent disease onset (Romagnani et al. 2002) and with active Graves' ophthalmopathy (Antonelli et al. 2006d). The CXCL10 secretion was synergistically induced by IFN $\gamma$ and TNF $\alpha$ in isolated thyrocytes in vitro (Garcia-Lopez et al. 2001, Antonelli et al. 2006d).

Anti-thyroid drugs (ATDs) used in the treatment of hyperthyroidism due to GD, in addition to its effect on thyroperoxidase, inhibited cell-mediated and humoral immune reactions (Volpé 2001, Laurberg 2006). While some investigators supported an immunosuppressive effect on immune system cells (Mc Gregor et al. 1980), other authors favored a direct effect exerted primarily on the thyroid cells, with secondary effects on the immune system via reduced thyrocyte-immunocyte signaling (Volpé 2001, Laurberg 2006).

Methimazole (MMI), in particular, has been reported to interfere with immunological signals associated with GD hyperthyroidism (Mc Gregor et al. 1980, Laurberg 2006) and decrease CXCL10 serum levels (Antonelli et al. 2006b,c). The reduction in circulating CXCL10 levels induced by MMI might suggest that this drug could target thyrocytes as a source of CXCL10.

To our knowledge, the synergistic effect of TNF $\alpha$ on IFN $\gamma$ induced CXCL10 secretion in human thyrocytes has yet to be clarified and it has not been elucidated whether MMI is able to exert any direct effect on these cells. Since we hypothesized that MMI might hamper the cytokine-induced biological pathway(s) leading to CXCL10 secretion, we investigated the mechanisms underlying TNF $\alpha+$ IFN $\gamma$ synergistic effect on CXCL10 secretion in cultured human thyrocytes, and the modulation, if any, by MMI on CXCL10 secretion in the cells stimulated with Th1-type cytokines. We utilized for comparison a peroxisome proliferator-activated receptor $\gamma$ (PPAR $\gamma$ ) agonist, rosiglitazone (RGZ), a drug for type 2 diabetes treatment, since it has been recently reported to suppress IFN $\gamma+$ TNF $\alpha$-induced CXCL10 secretion in human thyroid follicular cells of GD patients (Antonelli et al. 2006b,d).

\section{Materials and Methods}

\section{Chemicals}

Dulbecco's modified Eagle's medium (DMEM)/Ham's F12 medium (1:1) with and without phenol red, $\mathrm{Ca}^{2+} / \mathrm{Mg}^{2+}$-free PBS, BSA fraction $\mathrm{V}$, glutamine, antibiotics, collagenase type IV, $\mathrm{NaOH}$, Bradford reagent, and MMI were from Sigma-Aldrich Corp. The protein measurement kit was obtained from Bio-Rad Laboratories Inc. Fetal bovine serum was purchased from Unipath (Bedford, UK). IFN $\gamma$, TNF $\alpha$, and ELISA kit for CXCL10 measurement were from R\&D Systems (Minneapolis, MN, USA). Mouse monoclonal anti-thyreoglobulin antibody was from Cell Marque Corporation (Hot Spring, AR,
USA). Goat polyclonal anti-Pax8 antibody was from Abcam plc (Cambridge, UK). For flow cytometry analysis, PE-conjugated anti-CD119 (GIR-208, mouse IgG1) mAb was from BD Biosciences (Mountain View, CA, USA), the PE-conjugated anti-TNFR2 (22235.311, mouse IgG2a) $\mathrm{mAb}$ was purchased from R\&D Systems, and conjugated isotype-matched control Abs were from Southern Biotechnology Associated Inc. (Birmingham, AL, USA; mouse IgG1:clone 15H6, mouse IgG2a:clone HOPC-1). $\beta$-Mercaptoethanol was purchased from Fluka Biochemika Ultra (Buchs, Switzerland). For RNA extraction, RNeasy Mini reagent kit was from Quiagen Italy. TaqMan Reverse Transcription Reagents kit, all primer/probe mixes (Taqman Gene Expression Assays), CXCL10 (ID number Hs00171042-m1), IFN $\gamma \mathrm{R}$ (ID number Hs00166223-m1), Pax8 (ID number Hs00247586-m1), and $1 \times$ Universal Master Mix were from Applied Biosystems (Forster City, CA, USA). Quantitative PCR human reference total RNA was purchased from Stratagene (La Jolla, CA, USA). RGZ was from Glaxo (Welwyn, UK). For immunofluorescence, rabbit polyclonal antihuman primary antibody against nuclear factor- $\kappa \mathrm{B}(\mathrm{NF}-\kappa \mathrm{B})$ p65 (C-20) was from Santa Cruz Biotechnology (Santa Cruz, CA, USA) and Alexa Fluor 488 goat anti-rabbit conjugate antibody was from Molecular Probes (Eugene, OR, USA). Plasticware for cell cultures and disposable filtration units for growth media preparation were purchased from Corning (Milan, Italy).

\section{Cell cultures}

Primary cultures of thyrocytes were obtained from internodular parenchyma of thyroid tissues derived from 15 patients who underwent surgery for multinodular goiter (10 females: age range $37-83$ years and 5 males: age range 32-81 years). Certificates of consent were obtained. Patients did not receive any specific treatment for thyroid disease; thyroid hormones and thyroid autoantibody measurements were in normal range. Thyrocytes were prepared as previously described (Garcia-Lopez et al. 2001) with some modifications. Briefly, tissues were minced to fragments as small as possible and treated with $2 \mathrm{mg} / \mathrm{ml}$ bacterial collagenase in PBS for $45 \mathrm{~min}$ at $37^{\circ} \mathrm{C}$. Digested tissues were mechanically dispersed until a homogeneous suspension was obtained. After washing with PBS, the cell suspension was cultured in DMEM/Ham's F-12 medium (1:1) supplemented with $10 \% \mathrm{FBS}, 2 \mathrm{mmol} / \mathrm{l}$ glutamine, $100 \mathrm{U} / \mathrm{ml}$ penicillin, and $100 \mu \mathrm{g} / \mathrm{ml}$ streptomycin in a fully humidified atmosphere of $95 \%$ air-5\% $\mathrm{CO}_{2}$ in plastic $100 \mathrm{~mm}$ dishes. Cells began to emerge within $48 \mathrm{~h}$ and were used within the fifth-sixth passage. Human thyrocytes expressed paired box (Pax)8, a thyroid-specific transcription factor (Kang et al. 2001), and were positively stained for thyroglobulin and Pax8 (data not shown). 


\section{CXCL10 secretion assay}

For CXCL10 secretion assays, 4000 cells were seeded onto 96-well plates in growth medium. After $24 \mathrm{~h}$, the growth medium was removed and cells were washed in PBS and incubated in phenol red- and serum-free medium. After $24 \mathrm{~h}$, different stimuli were added in phenol red- and serum-free medium with $0 \cdot 1 \%$ BSA $(200 \mu \mathrm{l} /$ well). Cells in phenol red- and serum-free medium containing $0 \cdot 1 \%$ BSA and vehicle (absolute ethanol, 0.47\%, vol/vol) were used as control. For dose-response assays, cells were incubated for $24 \mathrm{~h}$ with $\mathrm{TNF} \alpha$ at $0 \cdot 1,1,10,100$, and $500 \mathrm{ng} / \mathrm{ml}$ or IFN $\gamma$ at 10, 100, 1000, 5000, and $10000 \mathrm{U} / \mathrm{ml}$, alone or combined with $10 \mathrm{ng} / \mathrm{ml}$ of $\mathrm{TNF} \alpha$; or with a combination of IFN $\gamma(1000 \mathrm{U} / \mathrm{ml})+\mathrm{TNF} \alpha(10 \mathrm{ng} / \mathrm{ml})$ in the presence or absence of MMI $(1,2 \cdot 5,5,10,25,50,100$, 200, 300, 500, and $1000 \mathrm{ng} / \mathrm{ml})$ or RGZ $(0 \cdot 025,0 \cdot 05$, $0 \cdot 1,0 \cdot 25,0 \cdot 5,1,2 \cdot 5,5,10,20$, and $30 \mu \mathrm{M})$. The supernatant was harvested and kept frozen at $-20{ }^{\circ} \mathrm{C}$ until CXCL10 ELISA was performed. Experiments were performed in triplicate or quadruplicate with 4-7 different cell preparations.

\section{CXCL10 ELISA}

CXCL10 levels were measured in culture supernatants (diluted 1:20-1:30) using commercially available kits, according to the manufacturer's recommendations. The sensitivity ranged from 0.41 to $4.46 \mathrm{pg} / \mathrm{ml}$; mean minimum detectable dose was $1.67 \mathrm{pg} / \mathrm{ml}$. The intraand inter-assay coefficients of variation were $3 \cdot 1 \%$ and $6.7 \%$ respectively. Samples were assayed in triplicate or quadruplicate. Quality control pools of low, normal, or high concentrations for all parameters were included in each assay. The obtained results, expressed as $\mathrm{pg} / \mathrm{ml}$, were normalized by total cell protein amount. Protein extraction was performed on the cell layer in the 96-well plates using $1 \mathrm{M} \mathrm{NaOH}$ for $5 \mathrm{~min}$, followed by Bradford reagent for 10-15 min. Protein concentration was measured by spectrophotometric analysis at $595 \mathrm{~nm}$.

\section{Flow cytometry analysis}

For cytometry analysis, cells were seeded onto $100 \mathrm{~mm}$ dishes in growth medium. Since the cultures were near confluent (about $10^{6}$ ), the growth medium was removed and cells were washed in PBS and incubated in phenol red- and serum-free medium for $24 \mathrm{~h}$. Thereafter, cells were stimulated for $24 \mathrm{~h}$ with $\operatorname{IFN} \gamma(1000 \mathrm{U} / \mathrm{ml})$ or $\mathrm{TNF} \alpha(10 \mathrm{ng} / \mathrm{ml})$ in phenol red- and serum-free medium with $0 \cdot 1 \%$ BSA. Cells in phenol red- and serum-free medium containing $0 \cdot 1 \%$ BSA and vehicle (absolute ethanol, $0 \cdot 47 \%$, vol/vol) were used as control. Flow cytometry analysis on cell suspensions was performed as detailed elsewhere (Annunziato et al. 2002). Briefly, $10^{5}$ cells were incubated with the specific or the isotype control $\mathrm{mAb}$ at $+4{ }^{\circ} \mathrm{C}$ for $30 \mathrm{~min}$; cells were then washed with PBS ( $\mathrm{pH} 7 \cdot 2$ ) containing $0 \cdot 5 \%$ BSA and analyzed on a BDLSRII cytofluorimeter using the Diva software (BD Biosciences). Ten thousand events for each sample were acquired. The area of positivity was determined using an isotype-matched $\mathrm{mAb}$. Experiments were performed at least four times with 4-8 different cell preparations.

\section{RNA extraction}

For mRNA analysis, cells (500 000 in $60 \mathrm{~mm}$ dishes) were maintained in phenol red- and serum-free medium for $24 \mathrm{~h}$. Then, cells were incubated in phenol red- and serum-free medium containing $0 \cdot 1 \%$ BSA with different stimuli, according to the following protocol: IFN $\gamma$ $(1000 \mathrm{U} / \mathrm{ml})$ or $\mathrm{TNF} \alpha(10 \mathrm{ng} / \mathrm{ml})$ alone or combined; TNF $\alpha(10 \mathrm{ng} / \mathrm{ml})$ combined with MMI $(300 \mathrm{ng} / \mathrm{ml})$ or RGZ $(5 \mu \mathrm{M})$. Cells in phenol red- and serum-free medium containing $0 \cdot 1 \%$ BSA and vehicle (absolute ethanol, $0 \cdot 47 \%$, vol/vol) were used as control. Thereafter, cells were trypsinized, washed twice in PBS, and pelleted before lysis. Cell pellet (stored at $-80^{\circ} \mathrm{C}$ ) was resuspended in $350 \mu \mathrm{l}$ of RLT plus $\beta$-mercaptoethanol (10 $\mu \mathrm{l} \beta$-mercaptoethanol per $\mathrm{ml}$ of RLT buffer). Total RNA from the cells was extracted with the RNeasy Mini reagent kit according to the manufacturer's recommendations. RNA concentration and quality were measured by NanoDrop ND-1000 spectrophotometer (NanoDrop Technologies, Wilmington, DE, USA). Experiments were performed three/four times with different cell preparations.

\section{Real-time PCR}

Total RNA (400 ng) was reverse transcribed using TaqMan Reverse Transcription Reagents kit. Reverse transcription was performed in a final volume of $80 \mu$ containing $500 \mathrm{mM}$ $\mathrm{KCl}, 0 \cdot 1 \mathrm{mM}$ EDTA, $100 \mathrm{mM}$ Tris- $\mathrm{HCl}(\mathrm{pH} 8 \cdot 3), 5.5 \mathrm{mM}$ $\mathrm{MgCl}_{2}, 500 \mu \mathrm{M}$ of each dNTP, $2 \cdot 5 \mu \mathrm{M}$ random examers, $0 \cdot 4 \mathrm{U} / \mu \mathrm{l}$ RNase inhibitor, and $1 \cdot 25 \mathrm{U} / \mu \mathrm{l}$ Multiscribe Reverse Transcriptase. The reverse transcription reaction was performed at $25^{\circ} \mathrm{C}$ for $10 \mathrm{~min}, 48^{\circ} \mathrm{C}$ for $30 \mathrm{~min}$, and $95^{\circ} \mathrm{C}$ for $3 \mathrm{~min}$. Measurement of gene expression was performed by quantitative real-time PCR (TaqMan). The amount of target, normalized to an endogenous reference (18s, pre-developed TaqMan Assay Reagents) and relative to a calibrator (Quantitative PCR human reference total RNA), was given by $2^{-\Delta \Delta C t}$ calculation (Livak \& Schmittgen 2001). The formula applied is $\Delta \Delta \mathrm{Ct}=\left(\mathrm{Ct}_{\text {target gene }}-\mathrm{Ct}_{18 \mathrm{~s}}\right)-$ $\left(\mathrm{Ct}_{\text {target gene calibrator }}-\mathrm{Ct}_{18 \mathrm{~s}}\right.$ calibrator $)$. For each sample, $12.5 \mathrm{ng}$ of cDNA were added to $10 \mu \mathrm{l}$ of PCR mix containing each primer/probe mix and $1 \times$ Universal Master Mix. The samples were then subjected to 40 cycles of amplification at $95^{\circ} \mathrm{C}$ for $15 \mathrm{~s}$ and $60{ }^{\circ} \mathrm{C}$ for $60 \mathrm{~s}$ in the $\mathrm{ABI}$ Prism 7700 Sequence Detector (Applied Biosystems). 


\section{Immunofluorescence microscopy}

Ten thousand cells were seeded onto glass coverslips in growth medium for $24 \mathrm{~h}$ and then incubated with serum-free medium overnight, before treatment with TNF $\alpha$ $(10 \mathrm{ng} / \mathrm{ml})$ alone or combined with IFN $\gamma(1000 \mathrm{U} / \mathrm{ml})$, in the presence or absence of MMI $(300 \mathrm{ng} / \mathrm{ml})$ or RGZ $(5 \mu \mathrm{M})$ for additional $24 \mathrm{~h}$. Cells in phenol red- and serum-free medium containing $0 \cdot 1 \%$ BSA and vehicle (absolute ethanol, $0 \cdot 47 \%$, vol/vol) were used as control. For method specificity, slides lacking the primary antibodies or stained with the corresponding nonimmune serum were processed. After washing twice with PBS, cells were fixed with $3 \cdot 7 \%$ paraformaldehyde ( $\mathrm{pH} \mathrm{7.4)} \mathrm{for} 10 \mathrm{~min}$ and then permeabilized for $10 \mathrm{~min}$ with PBS with $0 \cdot 1 \%$ Triton X-100. Immunostaining was performed as described previously (Vannelli et al. 1995) using primary antibody against NF- $\kappa \mathrm{B}$ p65 (1:100), followed by Alexa Fluor 488 conjugate secondary antibody $(1: 200)$. The slides were examined with a phase contrast microscope (Nikon Microphot-FX microscope, Nikon, Tokyo, Japan). Experiments were performed thrice with different cell preparations.

\section{Statistical analysis}

The statistical analysis was performed using SPSS 12.0 software package (SPSS for Windows 12.0; SPSS Inc. Chicago, IL, USA). The Kolmogorov-Smirnov test was used to test for normal distribution of the data. One-way ANOVA was applied. A $P$ value $<0.05$ was considered significant and was corrected for comparisons using the Dunnett's post hoc test. Data are expressed as mean \pm s.E.M. The computer program ALLFIT (NIH, Bethesda, MD, USA; De Lean et al. 1978) was used for analysis of sigmoid dose-response curves to obtain estimates of $\mathrm{IC}_{50}$ of MMI and RGZ.

\section{Results}

In human thyrocytes, 24-h treatment with increasing concentration of IFN $\gamma(10-10000 \mathrm{U} / \mathrm{ml})$ significantly increased CXCL10 protein secretion in the supernatant over undetectable basal levels in control cells $(P<0 \cdot 01$ or $P<0.05$ versus control; Fig. 1A). This effect was dose dependent and did not achieve plateau $(125 \cdot 0 \pm 16 \cdot 96 \mathrm{pg} / \mu \mathrm{g}$ protein, mean value at highest dose). Treatment with increasing doses of TNF $\alpha(0 \cdot 1-100$ and $500 \mathrm{ng} / \mathrm{ml})$ enhanced CXCL10 secretion over control levels as well $(P<0 \cdot 01$ or $P<0.05$ starting from $10 \mathrm{ng} / \mathrm{ml}$; Fig. 1B), although the secreted amount of chemokine was low $(13 \cdot 49 \pm 4 \cdot 49 \mathrm{pg} / \mu \mathrm{g}$ protein, mean value at plateau).

The simultaneous addition of a fixed dose of TNF $\alpha$ $(10 \mathrm{ng} / \mathrm{ml})$ to IFN $\gamma(10-10000 \mathrm{U} / \mathrm{ml})$ magnified the IFN $\gamma$ induced CXCL10 secretion until the maximal cell response was evoked $(2866 \cdot 35 \pm 229 \cdot 43 \mathrm{pg} / \mu \mathrm{g}$ protein, mean value at plateau) at each tested dose $(P<0 \cdot 01$ or $P<0 \cdot 05$ versus control and versus IFN $\gamma$ alone corresponding dose), confirming the strong synergistic effect of the combined cytokines (Fig. 1C). Combination of TNF $\alpha(10 \mathrm{ng} / \mathrm{ml})$ and IFN $\gamma(1000 \mathrm{U} / \mathrm{ml})$ yielded the highest response, very much in agreement with previous studies (Antonelli et al. 2006d) and, therefore, it was utilized for all subsequent experiments. Taqman real-time PCR analysis confirmed that either IFN $\gamma$ $(1000 \mathrm{U} / \mathrm{ml})$ or $\mathrm{TNF} \alpha(10 \mathrm{ng} / \mathrm{ml})$ similarly upregulated CXCL10-specific mRNA, while cytokine combination resulted in about a 23-fold increase in CXCL10 mRNA, when compared with single cytokine-induced expression $(P<0 \cdot 01$ or $P<0 \cdot 05$ versus control, $P<0 \cdot 05$ versus INF $\gamma-$ induced expression; Fig. 1D).

Cytokines are known to interact through the reciprocal modulation of their receptors. To verify whether the mechanism underlying $\mathrm{TNF} \alpha$ and IFN $\gamma$ synergism involved this mechanism in thyrocytes, we performed flow cytometry and mRNA analysis of IFN $\gamma$ and TNF $\alpha$ receptors (IFN $\gamma \mathrm{R}$ and $\mathrm{TNF} \alpha \mathrm{R}$, type I or II) in thyrocytes stimulated with $\mathrm{TNF} \alpha(10 \mathrm{ng} / \mathrm{ml})$ or IFN $\gamma(1000 \mathrm{U} / \mathrm{ml})$. As shown in Fig. 2A upper panel, IFN $\gamma \mathrm{R}$ protein membrane expression increased in thyrocytes treated with TNF $\alpha$ versus control cells $(28 \cdot 82 \pm 3 \cdot 11 \%$ vs $5 \cdot 42 \pm 0 \cdot 63 \%, P<0 \cdot 01)$, while IFN $\gamma$ did not show significant effect. Figure $2 \mathrm{~A}$ lower panel depicts a representative experiment out of eight. No significant effect on TNF $\alpha$ RI or II (data not shown) was observed. The mRNA analysis of IFN $\gamma \mathrm{R}$ also revealed a significant TNF $\alpha$ induced increase in the IFN $\gamma \mathrm{R}$ gene over basal level $(P<0 \cdot 01$ versus control) - although the increase in the protein was much higher - whereas IFN $\gamma$ did not exert significant effect on the specific messenger, as shown in Fig. $2 \mathrm{~B}$.

To investigate the possible role of MMI in CXCL10 secretion induced by proinflammatory cytokines in human thyrocytes, cells were simultaneously incubated with a combination of IFN $\gamma(1000 \mathrm{U} / \mathrm{ml})$ and TNF $\alpha(10 \mathrm{ng} / \mathrm{ml})$ and increasing concentrations of MMI $(1,2 \cdot 5,5,10,25,50$, $100,200,300,500$, and $1000 \mathrm{ng} / \mathrm{ml})$ or RGZ $(0 \cdot 025,0 \cdot 05$, $0 \cdot 1,0 \cdot 25,0 \cdot 5,1,2 \cdot 5,5,10,20$, and $30 \mu \mathrm{M})$ used for comparison. The first two lowest doses of each molecule ( 1 and $2 \cdot 5 \mathrm{ng} / \mathrm{ml}$ for MMI; $0 \cdot 025$ and $0 \cdot 05 \mu \mathrm{M}$ for RGZ) were reported only in ALLFIT interpolation.

The drug concentrations were selected on the basis of their near therapy doses $(300 \mathrm{ng} / \mathrm{ml}=2 \cdot 63 \mu \mathrm{M}$ for $\mathrm{MMI}$ and $5 \mu \mathrm{M}$ for RGZ respectively) according to their pharmacokinetics $\left(C_{\max }\right.$ and area under the time-concentration curve, AUC).

As shown in Fig. 3A, 24-h cell incubation with MMI decreased, in a dose-dependent manner, cytokine-induced CXCL10 secretion, significantly from $10 \mathrm{ng} / \mathrm{ml}(P<0 \cdot 01$ or $P<0 \cdot 05$ versus IFN $\gamma+$ TNF $\alpha$-treated cells).

Similarly, RGZ dose-dependently inhibited CXCL10 secretion significantly (Fig. 3B) from $1 \mu \mathrm{M}(P<0 \cdot 01$ versus IFN $\gamma+$ TNF $\alpha$-treated cells).

MMI and RGZ exerted a comparable inhibitory effect on CXCL10 secretion, as confirmed by the simultaneous fitting using ALLFIT program (De Lean et al. 1978) of the inhibitory 


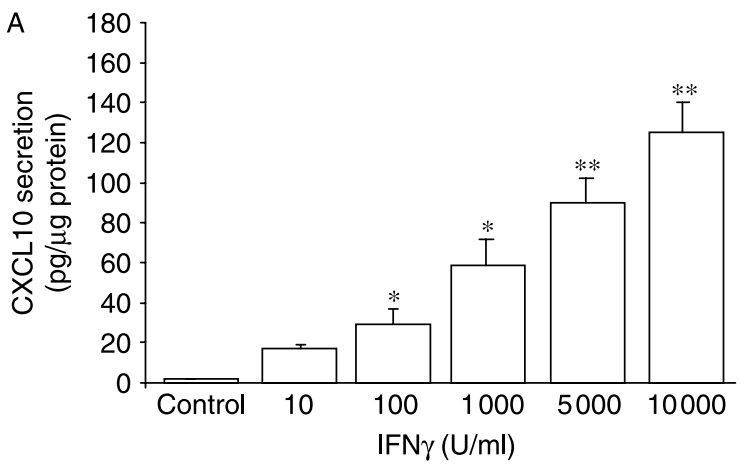

B


curves, showing no statistically significant difference in $50 \%$ effective concentration $\left(\mathrm{IC}_{50}=0 \cdot 29 \pm 0.05 \mu \mathrm{M}, P=0 \cdot 21\right)$, as shown in Fig. 3C. To verify whether the inhibitory effect of both drugs somehow affected the mechanism of synergy between the two cytokines, we analyzed IFN $\gamma \mathrm{R}$ expression induced by $\mathrm{TNF} \alpha(10 \mathrm{ng} / \mathrm{ml})$ in the presence of MMI (300 $\mathrm{ng} / \mathrm{ml})$ and RGZ $(5 \mu \mathrm{M})$ respectively.

Flow cytometry demonstrated that the treatment of thyrocytes with MMI for $24 \mathrm{~h}$ significantly reduced IFN $\gamma \mathrm{R}$ membrane protein expression induced by TNF $\alpha(17 \cdot 4 \pm 3 \cdot 8 \%$ vs $30 \pm 1 \cdot 5 \%$ respectively, $P<0 \cdot 05$ ), while R GZ did not exert any significant effect (Fig. 4A). Real-time PCR analysis of specific mRNA confirmed that MMI significantly reduced IFN $\gamma \mathrm{R}$ gene expression induced by TNF $\alpha(P<0 \cdot 01$ versus TNF $\alpha$-induced expression), although to a lower extent with respect to protein, while RGZ showed no effect (Fig. 4B).

In order to assess whether MMI or RGZ impaired the pathway of NF- $\kappa \mathrm{B}$, a pleiotropic transcriptional factor tightly associated with several cellular biological functions (Gilmore 2006) and specifically activated by TNF $\alpha$, we set up a nuclear translocation assay.

Stimulation with TNF $\alpha$ alone $(10 \mathrm{ng} / \mathrm{ml}$; Fig. $5 \mathrm{~B})$ or combined with IFN $\gamma(1000 \mathrm{U} / \mathrm{ml}$; Fig. 5C) resulted in the same compact increase (nuclear staining with TNFa: $91 \cdot 42 \pm 2 \cdot 13 \%$; nuclear staining with $\mathrm{TNF} \alpha+\mathrm{IFN} \gamma$ : $89 \cdot 82 \pm 2 \cdot 48 \%$ ) of NF- $\kappa B$ translocation from the cytoplasmic to the nuclear compartment. In Fig. 5A, control cells are depicted, showing $1 \cdot 14 \pm 0 \cdot 64 \%$ nuclear staining for NF$\kappa \mathrm{B}$. IFN $\gamma$ alone did not exert any effect on NF- $\kappa \mathrm{B}$ (data not shown). Since the effect of each drug with TNF $\alpha$ alone or

Figure 1 CXCL10 secretion is induced by IFN $\gamma$ and TNF $\alpha$ in human thyrocytes and potentiated by synergism between cytokines. (A) Increasing concentrations of IFN $\gamma(10-10000 \mathrm{U} / \mathrm{ml})$ significantly enhanced dose-dependently CXCL10 secretion versus almost undetectable levels in control cells $(* P<0 \cdot 05, * * P<0 \cdot 01)$ and did not reach a plateau. Amount of CXCL10 secretion ranged from $16 \cdot 94 \pm 1 \cdot 01$ to $125 \cdot 0 \pm 16 \cdot 96 \mathrm{pg} / \mu \mathrm{g}$ protein, lowest to highest dose. (B) Treatment with increasing concentration of TNF $\alpha$ $(0 \cdot 1-100$ and $500 \mathrm{ng} / \mathrm{ml})$ significantly increased CXCL10 secretion $\left({ }^{*} P<0 \cdot 05,{ }^{* *} P<0.01\right.$ versus control), although to a low extent $(3 \cdot 49 \pm 0 \cdot 98-13 \cdot 49 \pm 4 \cdot 49 \mathrm{pg} / \mu \mathrm{g}$ protein, lowest to highest dose). (C) A fixed dose of TNF $\alpha(10 \mathrm{ng} / \mathrm{ml})$ enhanced CXCL10 secretion induced by IFN $\gamma\left({ }^{*} P<0 \cdot 05,{ }^{* *} P<0 \cdot 01\right.$ versus control cells, or versus IFN $\gamma$ alone corresponding dose, ${ }^{\circ} P<0.05$ versus preceding dose). CXCL10 levels ranged from $1225 \cdot 50 \pm 41 \cdot 09$ to $2866 \cdot 35 \pm$ $229.43 \mathrm{pg} / \mu \mathrm{g}$ protein, lowest to highest dose. Synergism between the two cytokines effect, initially dose dependent, reached a plateau at the combination of IFN $\gamma(1000 \mathrm{U} / \mathrm{ml})$ and TNF $\alpha(10 \mathrm{ng} / \mathrm{ml})$. (D) mRNA expression of CXCL10 in thyrocytes treated with IFN $\gamma$ $(1000 \mathrm{U} / \mathrm{ml})$ and TNF $\alpha(10 \mathrm{ng} / \mathrm{ml})$ alone or combined. CXCL10 mRNA was upregulated by the two single cytokines and it was potentiated by their combination $\left({ }^{*} P<0 \cdot 05,{ }^{* *} P<0.01\right.$ versus control cells, ${ }^{\circ} P<0 \cdot 05$ versus IFN $\gamma$-induced expression).

(A-C: ordinate) CXCL10 secretion expressed as pg/ $\mu$ g protein; columns are mean \pm s.E.M. Data are derived from 4-7 separate experiments using distinct cell preparations ( $n=4$ and 7$)$. (D: ordinate) CXCL10 mRNA fold increase versus expression in control cells, taken as 1 . Data are derived from three separate experiments using distinct cell preparations $(n=3)$. 
A
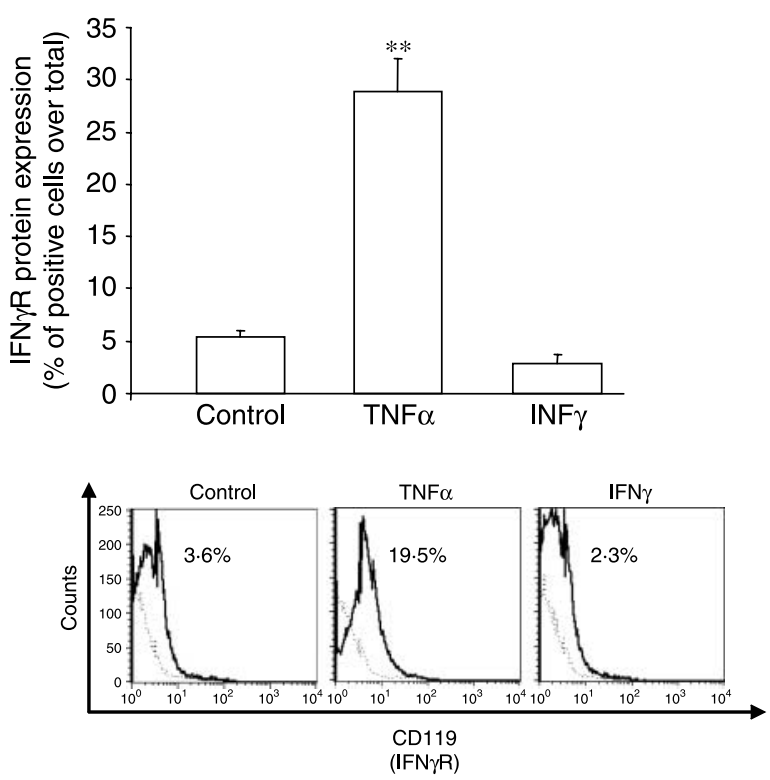

B

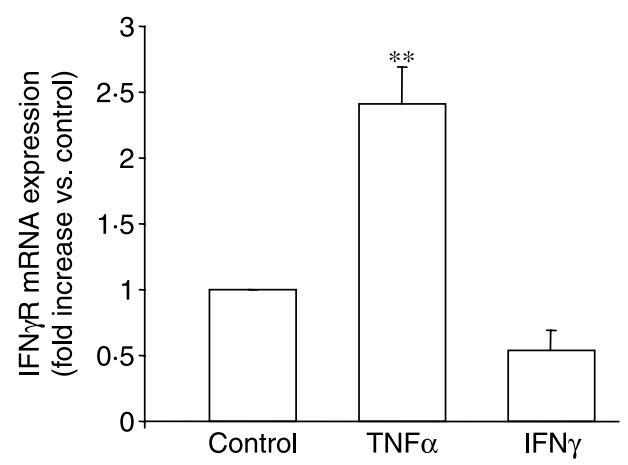

Figure $2 \mathrm{IFN} \gamma$ receptor (IFN $\gamma \mathrm{R}$ ) protein and gene expression are upregulated by TNF $\alpha$ in human thyrocytes. (A: upper panel) Flow cytometry revealed that TNF $\alpha(10 \mathrm{ng} / \mathrm{ml})$ upregulated IFN $\gamma \mathrm{R}$ membrane expression versus control cells $(28 \cdot 82 \pm 3 \cdot 11 \%$ vs $5 \cdot 42 \pm 0 \cdot 63 \%, * * P<0 \cdot 01$ versus basal expression in control cells); the treatment with its cognate ligand $(1000 \mathrm{U} / \mathrm{ml})$ did not show significant effect. (A: lower panel) IFN $\gamma \mathrm{R}$ (CD119) membrane expression in thyrocytes after 24-h culture in the indicated conditions is depicted (one representative experiment out of eight). Dotted histograms represent the staining obtained with control isotype-matched mAbs. In each, the percentage of positive cells is indicated. (B) Quantitative analysis using real-time RT-PCR of IFN $\gamma \mathrm{R}$ gene expression showed that TNF $\alpha(10 \mathrm{ng} / \mathrm{ml})$ significantly increased IFN $\gamma$ R gene expression $\left({ }^{* *} P<0 \cdot 01\right.$ versus control cells), while IFN $\gamma(1000 \mathrm{U} / \mathrm{ml})$ did not exert any significant effect. (A: upper panel ordinate) IFN $\gamma \mathrm{R}$ (CD119) membrane protein expression (percentage of positive cells over total), columns are mean \pm S.E.M. Results are derived from eight separate experiments using distinct cell preparations $(n=8)$. (B: ordinate) IFN $\gamma$ R mRNA expression (fold increase over expression in control cells, taken as 1); columns are mean \pm s.E.M. Results are derived from four separate experiments using distinct cell preparations $(n=4)$. combined with IFN $\gamma$ was the same, only the condition with cytokine combination has been reported.

Co-incubation with MMI (300 ng/ml) did not influence nuclear translocation as demonstrated by $83 \cdot 23 \pm 3 \cdot 21 \%$ of nuclear stain cell positivity (not significant versus cytokinetreated cells; Fig. 5D). Conversely, simultaneous incubation with RGZ $(5 \mu \mathrm{M})$ significantly reduced cytokine-stimulated NF- $\kappa$ B translocation, although more than $40 \%$ of cell nuclei still showed positivity (nuclear staining $42 \cdot 13 \pm 6 \cdot 85 \%, P<0 \cdot 01$ versus cytokine-treated cells; Fig. 5E). Columns in Fig. 5F summarize the results obtained with all treatments.

\section{Discussion}

This study shows that in human thyrocytes the synergistic effect of TNF $\alpha$ with IFN $\gamma$ on CXCL10 secretion is associated with a significant upregulation of IFN $\gamma \mathrm{R}$ driven by $\mathrm{TNF} \alpha$, both at protein and gene levels. We, for the first time, provide evidence in thyrocytes that MMI decreases cytokine-induced CXCL10 protein secretion by reducing TNF $\alpha$-induced upregulation of the IFN $\gamma$ membrane receptor. RGZ similarly decreases cytokine-induced CXCL10 secretion without affecting IFN $\gamma \mathrm{R}$ expression.

Interestingly, RGZ blocked TNF $\alpha$-mediated nuclear translocation of $\mathrm{NF}-\kappa \mathrm{B}$, pointing out that both drugs abrogated CXCL10 secretion likely by different pathways.

CXCL10 secretion potentiates the Th1 immunity-promoting inflammatory loop, driven by the recruited $\mathrm{CD} 4^{+} \mathrm{T}$ lymphocytes at inflammation sites, supporting T-cell proliferation and IFN $\gamma$ secretion (Campbell et al. 2004, Romagnani et al. 2004). It is well known that TNF $\alpha$ synergizes with IFN $\gamma$, modulating a number of different biological effects (Krakauer \& Oppenheim 1993). In particular, the synergy between the two cytokines is essential in potentiating inflammatory and Th1 immune responses promoted by IFN $\gamma$. To date, previous studies reported that CXCL10 secretion is triggered only by IFN $\gamma$ in different resident cell types (Rotondi et al. 2005, Antonelli et al. 2006d), while in microvascular endothelium TNF $\alpha$ has been reported to upregulate cytokines other than CXCL10 (Sana et al. 2005).

In our study, TNF $\alpha$ alone elicited a dose-dependent CXCL10 protein secretion in thyrocytes, although to a low extent. Accordingly, TNF $\alpha$ alone was able to upregulate CXCL10 mRNA similarly to IFN $\gamma$, suggesting that TNF $\alpha$, in addition to its synergistic effect with IFN $\gamma$, could contribute to initiating the Th1-mediated response.

Furthermore, the synergic action between the two cytokines in thyrocytes seems to be exerted mainly at a receptor level. A number of cytokines are known to amplify their biological responses both in vivo and in vitro via regulation of the expression of other cytokine receptors (Krakauer \& Oppenheim 1993).

We clearly demonstrated that TNF $\alpha$ upregulated IFN $\gamma \mathrm{R}$ at both protein and gene levels, while no significant effect was observed on TNFR type I or II expression (data not shown). Since dose-response curves with IFN $\gamma$ did not reach a 

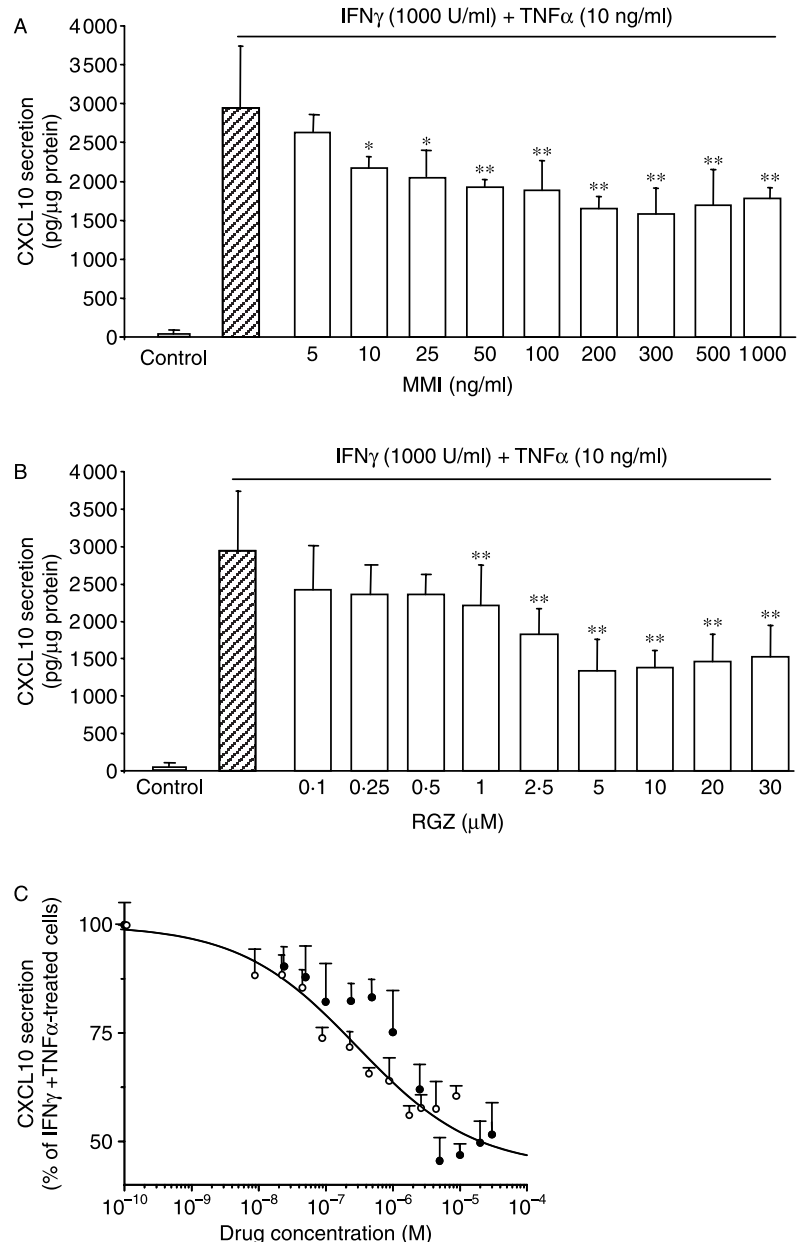

Figure $3 \mathrm{MMI}$ and RGZ dose-dependently inhibited CXCL10 secretion in human thyrocytes, with a similar potency. (A) Increasing doses of $\mathrm{MMI}(5,10,25,50,100,200,300,500$, and 1000 $\mathrm{ng} / \mathrm{ml})$ decreased CXCL10 secretion induced by IFN $\gamma(1000 \mathrm{U} / \mathrm{ml})$ and TNF $\alpha\left(10 \mathrm{ng} / \mathrm{ml} ;{ }^{*} P<0 \cdot 05,{ }^{* *} P<0 \cdot 01\right.$ versus IFN $\gamma+\mathrm{TNF} \alpha-$ treated cells). The maximum inhibitory concentration was $300 \mathrm{ng} / \mathrm{ml}$ corresponding to $2 \cdot 63 \mu \mathrm{M}$ ( $\max$ inhibition $46 \cdot 28 \pm 3 \cdot 04 \%$ ). (B) Incubation of thyrocytes with different doses of RZG $(0 \cdot 1,0 \cdot 25,0 \cdot 5$, $1,2 \cdot 5,5,10,20$, and $30 \mu \mathrm{M})$ similarly inhibited cytokine-induced CXCL10 secretion ( ${ }^{* *} P<0.01$ versus IFN $\gamma+$ TNF $\alpha$-treated cells).

The maximum inhibitory concentration was $5 \mu \mathrm{M}$ (max inhibition $54 \cdot 44 \pm 5 \cdot 34 \%$ ). (C) After ALLFIT interpolation, MMI (open circles) and RGZ (closed circles) exerted a similar inhibitory effect in thyrocytes, fitting the same curve $\left(\mathrm{IC}_{50}=0 \cdot 29 \pm 0 \cdot 05 \mu \mathrm{M}, P=0 \cdot 21\right)$. The two lowest extra doses reported in ALLFIT interpolation corresponded to 1 and $2.5 \mathrm{ng} / \mathrm{ml}$ for MMl and to 0.025 and $0.05 \mu \mathrm{M}$ for RGZ respectively. Drug concentrations were selected on the basis of their near therapy doses according to their pharmacokinetics $\left(C_{\max }\right.$ and area under the time-concentration curve, $A \cup C$ ). ( $A$ and $B$ : ordinate) CXCL10 secretion expressed as $\mathrm{pg} / \mu \mathrm{g}$ protein; columns are mean \pm s.E.M. Data derived from seven separate experiments using distinct cell preparations $(n=7)$. (C: ordinate) CXCL10 secretion expressed as percent variation (mean \pm s.E.M.) over the maximal IFN $\gamma+\mathrm{TNF} \alpha$-induced stimulation.
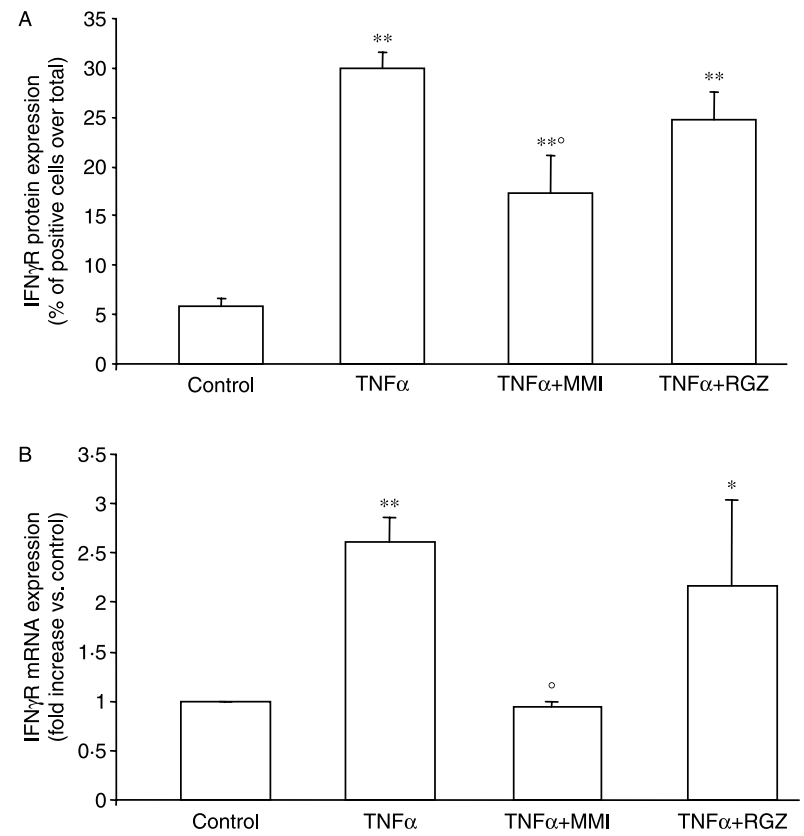

Figure 4 Modulation of IFN $\gamma \mathrm{R}$ protein and gene expression by $\mathrm{MMI}$ and RGZ in human thyrocytes. (A) Twenty-four-hour treatment with MMI $(300 \mathrm{ng} / \mathrm{ml})$ significantly reduced IFN $\gamma \mathrm{R}$ membrane protein expression induced by TNF $\alpha(10 \mathrm{ng} / \mathrm{ml} ; 17 \cdot 4 \pm 3 \cdot 8 \%$ vs $30 \pm 1 \cdot 5 \%$, ${ }^{\circ} P<0 \cdot 05$ versus TNF $\alpha$-induced expression, ${ }^{* *} P<0 \cdot 01$ versus control). Conversely, RGZ $(5 \mu \mathrm{M})$ did not exert any significant effect in TNF $\alpha$-treated cells. (B) MMI (300 ng/ml) inhibited TNF $\alpha$-induced IFN $\gamma \mathrm{R}$ mRNA upregulation $\left({ }^{\circ} P<0.01\right.$ versus TNF $\alpha$-induced expression, ${ }^{*} P<0 \cdot 05,{ }^{* *} P<0 \cdot 01$ versus control), while RGZ $(5 \mu \mathrm{M})$ showed no effect. (A: ordinate) IFN $\gamma \mathrm{R}(\mathrm{CD} 119)$ membrane protein expression (percentage of positive cells over total). Results are derived from four separate experiments using distinct cell preparations $(n=4)$. (B: ordinate) IFN $\gamma \mathrm{R}$ mRNA expression (fold increase versus expression in control cells, taken as 1); columns are mean \pm s.E.M. Results are derived from three separate experiments using distinct cell preparations $(n=3)$.

plateau, the increase, induced by $\mathrm{TNF} \alpha$, of IFN $\gamma \mathrm{R}$ expression may account for the raised magnitude of the response to IFN $\gamma$, in terms of CXCL10 protein secretion. Accordingly, TNF $\alpha$ was able to potentiate the amount of CXCL10 protein secretion $(\mathrm{ng} / \mathrm{ml}$ versus $\mathrm{pg} / \mathrm{ml}$ ) dosedependently induced by IFN $\gamma$, until the maximal cell response was evoked. CXCL10 mRNA specific amount resulted significantly increased in the presence of both cytokines. Since cells with higher number of specific receptors are able to respond to lower concentrations of IFN $\gamma, T N F \alpha$ could be critical in the pathogenesis of AITDs, in line with previous work highlighting the relevance of the TNF $\alpha$ pathway in GD (Diez et al. 2002).

Our data support the thyroid itself as the main site of CXCL10 secretion perpetuating the Th1-mediated autoimmune cascade in AITDs (Garcia-Lopez et al. 2001, Romagnani et al. 2002, Kemp et al. 2003, Antonelli et al. 2004). This is very much in agreement with recently published studies in patients showing the reduction of high CXCL10 serum levels in patients with GD after 
A

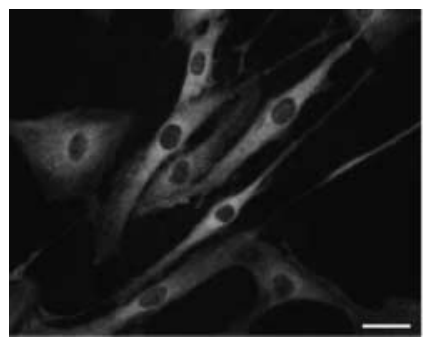

B

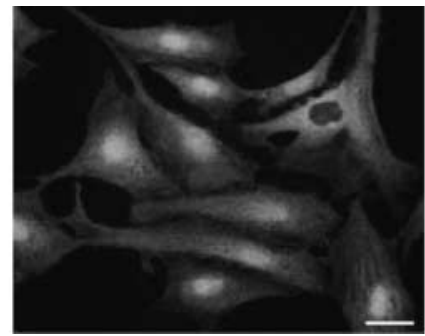

C

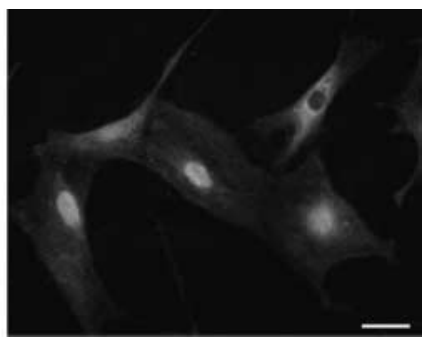

\section{D}

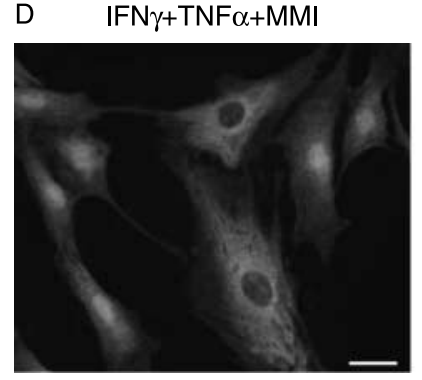

E IFN $\gamma+$ TNF $\alpha+R G Z$


Control

Figure 5 Microscopy assessment of NF- $\mathrm{B}$ activation in human thyrocytes. The nuclear accumulation of $\mathrm{NF}-\kappa \mathrm{B}$ p65 subunit in the presence or absence of TNF $\alpha(10 \mathrm{ng} / \mathrm{ml})$ alone or with IFN $\gamma(1000 \mathrm{U} / \mathrm{ml})$ and with MMI (300 ng/ml) or RGZ $(5 \mu \mathrm{M})$ was assessed by microscopy of thyrocytes stained with antihuman antibody against p65. (A) In control cells, p65 was distributed throughout the cytosol. (B and C) After stimulation with TNF $\alpha$ alone (B) or combined with IFN $\gamma(\mathrm{C})$, p65 consistently disappeared from the cytosol and accumulated in the nucleus, in most of the cells. (D) In cells stimulated by both cytokines and MMI, p65 subcellular distribution pattern was similar to that in cells stimulated with cytokines. (E) The simultaneous presence of RZG in cells treated with cytokines reduced more than 50\% p65 nuclear translocation induced by TNF $\alpha+$ IFN $\gamma$. Since the effect of each drug with TNF $\alpha$ alone or combined with IFN $\gamma$ was the same, only the condition with cytokine combination is reported. Bar: $100 \mu \mathrm{m}$. (F) Cells were scored as either positive or negative for nuclear p 65 and results were expressed as the percentage of positive cells \pm s.E.M. (calculated by counting the number of stained cells over total in 18 separate fields in each stained slide). Positive cells for nuclear p65 were virtually absent in control cells $(1 \cdot 14 \pm 0 \cdot 64 \%)$. The percentage of positive cells after stimulation was $91 \cdot 42 \pm 2 \cdot 13 \%$ with TNF $\alpha, 89 \cdot 82 \pm 2 \cdot 48 \%$ with TNF $\alpha+$ IFN $\gamma, 85 \cdot 12 \pm 2 \cdot 58 \%$ with TNF $\alpha$ and MMI, $83 \cdot 23 \pm$ $3 \cdot 21 \%$ with TNF $\alpha+$ IFN $\gamma$ and MMI, $51 \cdot 42 \pm 6 \%$ with TNF $\alpha$ and RGZ, and $42 \cdot 13 \pm 6 \cdot 85 \%$ with TNF $\alpha+$ IFN $\gamma$ and RGZ. ${ }^{* *} P<0 \cdot 01$ versus control; ${ }^{\circ} P<0 \cdot 01$ versus TNF $\alpha ;{ }^{\sharp} P<0 \cdot 01$ versus TNF $\alpha+$ IFN $\gamma$. (F: ordinate) p65 nuclear positive cells (percentage over total cells); columns are mean \pm S.E.M. Results are derived from three separate experiments using distinct cell preparations $(n=3)$. 
thyrodectomy (Antonelli et al. 2006b) or after treatment with ${ }^{131}$ I (Antonelli et al. 2007).

Treatment with thionamidein AITDs, in addition to its effect on hormone synthesis, is accompanied by a gradual remission of the autoimmune aberration in the majority of patients (Pinchera et al. 1969, Mc Gregor et al. 1980, Laurberg 2006). A recent report describes a reduction in CXCL10 circulating levels in hyperthyroid patients with GD under MMI therapy (Antonelli et al. 2006c).

We showed that MMI decreased proinflammatory cytokine-induced CXCL10 secretion in thyrocytes in vitro, throughout a strong reduction in TNF $\alpha$-induced IFN $\gamma \mathrm{R}$ membrane protein expression. This effect, matching a reduction in specific amount of IFN $\gamma \mathrm{R}$ mRNA, seems to be particularly relevant because it counteracts the magnitude of the CXCL10 secretion in response to IFN $\gamma$, as previously emphasized. Thus far, it turned out that MMI exerts its immunomodulatory effect on thyrocytes and this should not be surprising since it is well known that it concentrates in follicular cells and not in the surrounding interstitial tissue, where the infiltrating immunocompetent cells are present (Marchant et al. 1972).

Hyperthyroidism per se plays a minimal role in determining CXCL10 levels that, indeed, are strongly associated with the autoimmune process of the hyperthyroid phase in GD (Romagnani et al. 2002, Antonelli et al. 2006a), but not with toxic nodular goiter (Antonelli et al. 2007). In this light, MMI emerged as a particularly relevant therapy, since it targets the thyroid by dual action, both restoring euthyroidism and decreasing CXCL10 release by thyrocytes.

Concerning drug doses, we want to highlight that the concentrations used in our experiments were selected according to drug plasma or intraglandular concentration range following therapeutic doses, differently from previous in vitro studies that have used far higher drug concentrations than the concentration reached in the thyroid tissue in vivo (Mc Gregor et al. 1980).

Our studies on MMI were performed in comparison to RGZ, a pure PPAR $\gamma$ agonist, because it has been recently showed to reduce CXCL10 levels in thyroid follicular cells in GD patients (Antonelli et al. 2006d). PPAR $\gamma$ agonists are known to play an inhibitory role in the self-perpetuation of chemokine-mediated inflammatory processes in several human cell types (Su et al. 1999, Marx et al. 2000, Gosset et al. 2001, Antonelli et al. 2006d).

RGZ exerted its inhibitory effect on Th1-polarized response in thyrocytes without affecting IFN $\gamma \mathrm{R}$ expression. In human thyrocytes, RGZ significantly inhibited CXCL10 secretion at micromolar concentrations by inhibiting NF- $\kappa B$ activation, as demonstrated by the decrease of TNF $\alpha$ induced NF- $\kappa \mathrm{B}$ translocation in the cell nucleus. On the contrary, in other cellular models (colon cells transfected with an NF-KB-luciferase reporter element), the mechanism of CXCL10 decrease induced by PPAR $\gamma$ agonists seems to be NF- $\kappa B$ independent (Schaefer et al. 2005). Further studies are necessary to provide details on the RGZ mechanism of action, intended to elucidate the potential effect on Graves' ophthalmopathy. Indeed, while some authors have suggested (Antonelli et al. 2006d) its beneficial effect, there is experimental and clinical evidence that PPAR $\gamma$ agonists may impair the clinical course of Graves' ophthalmopathy by adipogenesis stimulation (Valyasevi et al. 2002, Starkey et al. 2003).

In summary, we have demonstrated a novel antiinflammatory effect of MMI that is able to revert Th1 cytokine-mediated CXCL10 secretion directly in thyroid cells by damping the mechanism underlying cytokine synergy. Although further investigations are needed to understand its signaling pathway, MMI targeted thyrocytes with the same pharmacological potency as RGZ, a regulator of the inflammatory response (Campbell 2005), likely acting through different mechanisms.

Given the pivotal role of IFN $\gamma$-induced chemokines in Th1-mediated autoimmune thyroid diseases (Rotondi et al. 2007), a combination of different drugs with the same inhibitory effect targeting different intracellular pathways could be a novel pharmacological tool, intended to decrease therapeutic doses and thus minimizing side effects, similar to immunosuppressive protocols for the treatment of other autoimmune diseases or allograft rejection.

\section{Acknowledgements}

The authors wish to thank Dr Sabino Scolletta, Department of Surgery and Bioengineering, University of Siena, Italy for his kind help with statistical analysis.

\section{Funding}

This research was supported by TRESOR (Tuscany REgional Study On Rosiglitazone) and MIUR (Ministero dell'Istruzione, dell'Università e della Ricerca). We declare that there is no conflict of interest that would prejudice the impartiality of the research reported.

\section{References}

Aniszewski JP, Valyasevi RW \& Bahn RS 2000 Relationship between disease duration and predominant orbital T cell subset in Graves' disease. Journal of Clinical Endocrinology and Metabolism 85 776-780.

Annunziato F, Cosmi L, Liotta F, Lazzeri E, Manetti R, Vanini V, Romagnani P, Maggi E \& Romagnani S 2002 Phenotype, localization, and mechanism of suppression of CD4 $(+) \mathrm{CD} 25(+)$ human thymocytes. Journal of Experimental Medicine 196 379-387.

Antonelli A, Rotondi M, Fallahi P, Romagnani P, Ferrari SM, Buonamano A, Ferrannini E \& Serio M 2004 High levels of circulating CXCL10 are associated with chronic autoimmune thyroiditis and hypothyroidism. Journal of Clinical Endocrinology and Metabolism 89 5496-5499.

Antonelli A, Rotondi M, Fallahi P, Romagnani P, Ferrari SM, Paolicchi A, Ferrannini E \& Serio M 2005 Increase of interferon-gamma inducible 
$\boldsymbol{\alpha}$-chemokine CXCL10 but not beta chemokine CCL2 serum levels in chronic autoimmune thyroiditis. European Journal of Endocrinology 152 171-177.

Antonelli A, Fallahi P, Rotondi M, Ferrari SM, Romagnani P, Grosso M, Ferrannini E \& Serio M 2006a Increased serum CXCL10 in Graves' disease or autoimmune thyroiditis is associated with hyper- or hypothyroidism per se, but is specifically sustained by the autoimmune, inflammatory process. European Journal of Endocrinology 154 651-658.

Antonelli A, Fallai P, Rotondi M, Ferrari SM, Serio M \& Miccoli P $2006 b$ Serum levels of the interferon- $\gamma$-inducible $\boldsymbol{\alpha}$-chemokine CXCL10 in patients with active Graves' disease, and modulation by methimazole therapy and thyroidectomy. British Journal of Surgery 93 1226-1231.

Antonelli A, Rotondi M, Fallahi P, Romagnani P, Ferrari SM, Barani L, Ferrannini E \& Serio M 2006c Increase of interferon- $\gamma$-inducible CXC chemokine CXCL10 serum levels in patients with active Graves' disease, and modulation by methimazole therapy. Clinical Endocrinology 64 189-195.

Antonelli A, Rotondi M, Ferrari SM, Fallahi P, Romagnani P, Franceschini SS, Serio M \& Ferrannini E 2006 $d$ Interferon- $\boldsymbol{\gamma}$-inducible $\boldsymbol{\alpha}$-chemokine CXCL10 involvement in Graves' ophthalmopathy: modulation by peroxisome proliferator-activated receptor- $\gamma$ agonists. Journal of Clinical Endocrinology and Metabolism 91 614-620.

Antonelli A, Rotondi M, Fallahi P, Grosso M, Boni G, Ferrari SM, Romagnani P, Serio M, Mariani G \& Ferrannini E 2007 Iodine-131 given for therapeutic purposes modulates differently interferon- $\gamma$-inducible $\boldsymbol{\alpha}$-chemokine CXCL10 serum levels in patients with active Graves' disease or toxic nodular goiter. Journal of Clinical Endocrinology and Metabolism 92 $1485-1490$

Aust G, Sittig D, Steinert M, Lamesch P \& Lohmann T 2002 Graves' disease is associated with an altered CXCR 3 and CCR 5 expression in thyroidderived compared to peripheral blood lymphocytes. Clinical and Experimental Immunology 127 479-485.

Campbell IW 2005 The clinical significance of PPAR gamma agonism. Current Molecular Medicine 5 349-363.

Campbell JD, Gangur V, Simons FE \& HayGlass KT 2004 Allergic humans are hyporesponsive to a CXCR 3 ligand-mediated Th1 immunity-promoting loop. FASEB Journal 18 329-331.

De Lean A, Munson PJ \& Rodbard D 1978 Simultaneous analysis of families of sigmoidal curves: application to bioassay, radioligand assay, and physiological dose-response curves. American Journal of Physiology 235 E97-E102.

Diez JJ, Hernanz A, Medina S, Bayon C \& Iglesias P 2002 Serum concentrations of tumour necrosis factor- $\alpha$ (TNF- $\alpha$ ) and soluble TNF- $\alpha$ receptor p55 in patients with hypothyroidism and hyperthyroidism before and after normalization of thyroid function. Clinical Endocrinology $\mathbf{5 7}$ 515-521.

Garcia-Lopez MA, Sancho D, Sanchez-Madrid F \& Marazuela M 2001 Thyrocytes from autoimmune thyroid disorders produce the chemokines IP-10 and Mig and attract CXCR3 + lymphocytes. Journal of Clinical Endocrinology and Metabolism 86 5008-5016.

Gilmore TD 2006 Introduction to NF-אB: players, pathways, perspectives. Oncogene 25 6680-6684.

Gosset P, Charbonnier AS, Delerive P, Fontaine J, Staels B, Pestel J, Tonnel AB \& Trottein F 2001 Peroxisome proliferator-activated receptor activators affect the maturation of human monocyte-derived dendritic cells. European Journal of Immunology 31 2857-2865.

Kang HC, Ohmori M, Harii N, Endo T \& Onaya T 2001 Pax8 is essential for regulation of the thyroglobulin gene by transforming growth factor-beta1. Endocrinology 142 267-275.

Kemp EH, Metcalfe RA, Smith KA, Woodroofe MN, Watson PF \& Weetman AP 2003 Detection and localization of chemokine gene expression in autoimmune thyroid disease. Clinical Endocrinology 59 207-213.

Krakauer T \& Oppenheim JJ 1993 IL-1 and tumor necrosis factor- $\alpha$ each up-regulate both the expression of IFN- $\gamma$ receptors and enhance IFN- $\gamma$ induced HLA-DR expression on human monocytes and a human monocytic cell line (THP-1). Journal of Immunology 150 1205-1211.

Laurberg P 2006 Remission of Graves' disease during anti-thyroid drug therapy. Time to reconsider the mechanism? European Journal of Endocrinology 155 783-786.
Livak K \& Schmittgen TD 2001 Analysis of relative gene expression data using Real-Time Quantitative PCR and the $2^{-\Delta \Delta \mathrm{Ct}}$ method. Methods $\mathbf{2 5}$ 402-408.

Marchant B, Alexander WD, Lazarus JH, Lees J \& Clark DH 1972 The accumulation of $35 \mathrm{~S}$-antithyroid drugs by the thyroid gland. Journal of Clinical Endocrinology and Metabolism 34 847-851.

Marx N, Mach F, Sauty A, Leung JH, Sarafi MN, Ransohoff RM, Libby P, Plutzky J \& Luster AD 2000 Peroxisome proliferator-activated receptor $\gamma$ activators inhibit IFN $\gamma$-induced expression of the T cell-active CXC chemokines IP-10, Mig, and I-TAC in human endothelial cells. Journal of Immunology 164 6503-6508.

Mc Gregor AM, Petersen MM, McLachlan SM, Rooke P, Smith BR \& Hall R 1980 Carbimazole and the autoimmune response in Graves' disease. New England Journal of Medicine 303 302-307.

Pinchera A, Liberti P, Martino E, Fenzi GF, Grasso L, Rovis L, Banchieri L \& Doria G 1969 Effects of antithyroid therapy on the long-acting thyroid stimulator and the antithyroglobulin antibodies. Journal of Clinical Endocrinology and Metabolism 29 231-238.

Romagnani P, Annunziato F, Lasagni L, Lazzeri E, Beltrame C, Francalanci M, Uguccioni M, Galli G, Cosmi L, Maurenzig L et al. 2001 Cell cycle dependent expression of CXC chemokine receptor 3 by endothelial cells mediates angiostatic activity. Journal of Clinical Investigation 107 53-63.

Romagnani P, Rotondi M, Lazzeri E, Lasagni L, Francalanci M, Buonamano A, Milani S, Vitti P, Chiovato L, Tonacchera M et al. 2002 Expression of IP-10/CXCL10 and Mig/CXCL9 in the thyroid and increased serum levels of IP-10/CXCL10 in the serum of subjects with recent onset Graves' disease. American Journal of Physiology 161 195-206.

Romagnani P, Lasagni L, Annunziato F, Serio M \& Romagnani S 2004 CXC chemokines: the regulatory link between inflammation and angiogenesis. Trends in Immunology 25 201-209.

Rotondi M, Lazzeri E, Romagnani P \& Serio M 2003 Role for interferon- $\gamma$ inducible chemokines in endocrine autoimmunity: an expanding field. Journal of Endocrinological Investigation 26 177-180.

Rotondi M, Falorni A, De Bellis A, Laureti S, Ferruzzi P, Romagnani P, Buonamano A, Lazzeri E, Crescioli C, Mannelli M et al. 2005 Elevated serum interferon- $\boldsymbol{\gamma}$-inducible chemokine-10/CXC chemokine ligand-10 in autoimmune primary adrenal insufficiency and in vitro expression in human adrenal cells primary cultures after stimulation with proinflammatory cytokines. Journal of Clinical Endocrinology and Metabolism 90 2357-2367.

Rotondi M, Chiovato L, Romagnani S, Serio M \& Romagnani P 2007 Role of chemokines in endocrine autoimmune diseases. Endocrine Reviews $\mathbf{2 8}$ 492-520.

Sana TR, Janatpour MJ, Sathe M, McEvoy LM \& McClanahan TK 2005 Microarray analysis of primary endothelial cells challenged with different inflammatory and immune cytokines. Cytokine 9 256-269.

Schaefer KL, Denevich S, Ma C, Cooley SR, Nakajima A, Wada K, Schlezinger J, Sherr D \& Saubermann LJ 2005 Intestinal antiinflammatory effects of thiazolidenedione peroxisome proliferator-activated receptor- $\gamma$ ligands on T helper type 1 chemokine regulation include nontranscriptional control mechanisms. Inflammatory Bowel Diseases 11 244-252.

Starkey K, Heufelder A, Baker G, Joba W, Evans M, Davies S \& Ludgate M 2003 Peroxisome proliferator-activated receptor- $\gamma$ in thyroid eye disease: contraindication for thiazolidinedione use? Journal of Clinical Endocrinology and Metabolism 88 55-59.

Su CG, Wen X, Bailey ST, Jiang W, Rangwala SM, Keilbaugh SA, Flanigan A, Murthy S, Lazar MA \& Wu GD 1999 A novel therapy for colitis utilizing PPAR $-\gamma$ ligands to inhibit the epithelial inflammatory response. Journal of Clinical Investigation 104 383-389.

Valyasevi RW, Harteneck DA, Dutton CM \& Bahn RS 2002 Stimulation of adipogenesis, peroxisome proliferator-activeted receptor- $\gamma(\operatorname{PPAR} \gamma)$, and thyrotropin receptor by PPAR $\gamma$ agonist in human orbital preadipocyte fibroblasts. Journal of Clinical Endocrinology and Metabolism 87 2352-2358.

Vannelli GB, Ensoli F, Zonefrati R, Kubota Y, Arcangeli A, Becchetti A, Camici G, Barni T, Thiele CJ \& Balboni GC 1995 Neuroblast long-term cell cultures from human fetal olfactory epithelium respond to odors. Journal of Neuroscience 15 4382-4394. 
Volpé R 2001 The immunomodulatory effects of anti-thyroid drugs are mediated via actions on thyroid cells, affecting thyrocyte-immunocyte signalling: a review. Current Pharmaceutical Design 7 451-460.

Wakelkamp IM, Bakker O, Baldeschi L, Wiersinga WM \& Prummel MF 2003 TSH-R expression and cytokine profile in orbital tissue of active vs. inactive Graves' ophthalmopathy patients. Clinical Endocrinology $\mathbf{5 8}$ 280-287.

Watson PF, Pickerill AP, Davies R \& Weetman AP 1995 Semiquantitative analysis of IL-1a, IL-6 and IL-8 mRNA expression by human thyrocytes. Journal of Molecular Endocrinology 15 11-21.

Weetman AP 2003 Autoimmune thyroid disease: propagation and progression. European Journal of Endocrinology 148 1-9.
Weetman AP 2004 Cellular immune responses in autoimmune thyroid disease. Clinical Endocrinology 61 405-413.

Weetman AP \& McGregor AM 1994 Autoimmune thyroid disease: further developments in our understanding. Endocrine Reviews 15 788-830.

Zlotnik A \& Yoshie O 2000 Chemokines: a new classification system and their role in immunity. Immunity 12 121-127.

Received in final form 2 August 2007

Accepted 3 August 2007

Made available online as an Accepted Preprint

7 August 2007 